\title{
Methodological Considerations: Convergences
}

\author{
Martha Frederiks and Dorottya Nagy
}

\section{1 Introduction}

Nemere Kerezsi's artwork In the apiary depicted on the cover of this book encapsulates several of the features that we as editors consider distinctive for a World Christianity approach. It epitomizes simultaneity of difference and balances uniqueness and connectedness in such a way that each geometric form is both distinct and complete, and a constitutive part of a larger entity. The fluid transitions between the forms project togetherness and oneness, yet there is no apparent center. To us, In the apiary represents a conceptual design that visualizes some of the fundamental theoretical ideas of a World Christianity approach. This World Christianity approach is still very much 'in the making'. Frederiks in this volume tentatively sketches some of the contours of such an approach from a religious studies perspective, stating that it

entails the conscious and consistent endeavour to study particular Christian communities, beliefs, or practices in the light of and in relation to Christianity's wider (hi)story, mindful of integrative and globalizing forces as well as of its multiple 'centers', trajectories, and agents, aware that Christianity's manifestations always shape and are shaped by broader political, socio-economic, and religious dynamics, cognizant of the diversity of beliefs and practices this has produced across time and space.

Frederiks, this volume

Nagy, working as a missiologist-theologian, has proposed diversity, unity, locality, and connectivity as the central concepts in a World Christianity approach. For her:

These concepts are all interrelated, creating overlapping webs of meaning. For example, unity and diversity gain meaning only through their connection through specific locations where these characteristics are expressed. In a sense, a single locality may contain multiple worlds, demonstrating complex change over time (chronology is also a key factor). Furthermore, these interactions are moderated through various types of 
power relations, which regulate all interactions in which humans are involved. Perceiving the world as constituted by multiple contexts in which humans interact with each other and with God (Nagy 20og:6), the researcher can define the context of a concrete research area only by pinning down the specific locality.

Nagy 2017: 147

As may be evident from the diverse disciplinary backgrounds of the contributors in this book, we as editors do not consider a World Christianity approach to be the proprium of theology and/or religious studies. Rather, we advocate multiple perspectivity, both in terms of multidisciplinary and in terms of representing a diversity of contexts and viewpoints. In this closing chapter we revisit the contributions to this volume in order to discern how the range of methods, perspectives, and insights discussed in the previous chapters, aid us in further developing and operationalizing a World Christianity approach.

As outlined in the introduction, the central concern of this book has been methodology. We have therefore structured this last chapter around five methodological clusters. Each cluster represents a methodological aspect that we consider critical to a World Christianity approach. The clusters converge around the topics of context, analytical concepts, methods, sources, and choosing a unit of analysis.

A key feature of a World Christianity approach as we envisage it, is attentiveness to Christianity/ies' entanglements with a wide variety of contexts. Christianity/ies shape and are shaped by contexts; imaginaries of connectedness and integrative forces that connect local expressions of Christianity/ Christianities only exist by virtue of these local manifestations. Or in the words of Nagy cited above, "unity and diversity gain meaning only through their connection through specific locations where these characteristics are expressed." A World Christianity approach therefore explicitly takes cognizance of the fact that ever-changing contexts constantly interact on manifestations, beliefs, and practices of the Christian tradition and, vice versa, that Christianity/ies also (co)shape and transform these contexts.

The chapters in this volume exemplify some of the manifold ways in which Christianities in context interact with and in their settings. As Nagy argues in her contribution and is evidenced in other contributions in this volume as well, contexts are not confined to the socio-economic and political configurations 
that shape a locality or particular geopolitical setting. Rather, contexts encompass "a diversity of perceptions, experiences, and processes of cohabitation within shared localities and beyond" (Nagy, this volume). Contexts can be digitally or discursively constructed as Van Liere demonstrates in his analysis of the representations of the Coptic migrant workers. They can consist of translocal networks as shown by both John and Lee and Chow. But they can also comprise of visions or globally connected movements in which people from different localities participate as Wild-Wood argues in her contribution on missionary sources, or of theological constructs, as Barreto's exposition on liberation theology shows. A World Christianity approach takes this wide diversity of contexts, and the way these contexts interact on each other and on Christianity/ies into account.

Several contributors signpost that also religious configurations are contexts that shape Christianity/ies; they observe that these religious contexts affect and fashion the modalities of interaction between Christianity/ies and other religious traditions. Van Liere for example highlights modalities of competition and rivalry, Haug's case-study of Thai comparative theology foregrounds convergences and a shared worldview, while Williams' research in Nigeria underscores the fuzziness and fluidity of religious belonging and identity, thus drawing attention to forms of 'boundary-crossing' between religious traditions. The chapters by Haug and Ariarajah underscore that the manner and extent to which Christianity is shaped by its religiously plural contexts, hinges on a constellation of factors, such as the size of the Christian community in relation to its a religiously plural context (minority/majority) and its theological conviction. Not every Christian community situated in a religiously plural setting for example allows the religious other(s) to interrogate and transform its faith expressions and theology. The contributions by Pratt on institutional responses to multireligiosity and by Ariarajah on the theological implications of living in a religiously plural world make clear that also within contexts, there can be different modalities of interaction simultaneously, depending on the situationality of the actors: where Pratt homes in on global institutional responses, Ariarajah argues that the attention for pluriformity in World Christianity discourses should also have implications for theological assessments of the religiously others.

The chapters by Pratt and by John underscore that religious contexts are not limited to the religiously other; the dynamics between various Christian expressions in past and present are also part of the religious configurations that interact on particular local Christianities. And as Van Geest and Wild-Wood make clear, often times these interactions are hierarchical and buttressed by power (be it military, political, economic or ideological); they often 
represent a quest to proclaim a particular interpretation 'catholic', and hence universally normative.

Several contributions also explicitly flag academia as a context of Christianity/ies, because of the critical role the academia plays in how Christian manifestations, beliefs, and practices are perceived, represented, and interpreted. It is predominantly the prerogative (and hence the power) of the academia, to develop concepts, theories, and interpretational frameworks for the study of Christianity/ies. Frederiks (2019, and this volume) for example points to the selective representation of Christianity/ies in current World Christianity debates, resulting in an underrepresentation (factual as well as theoretical) of for example minority churches in the Sahel and North Africa, and Eastern and Oriental Orthodoxy. John interrogates the validity and hegemony of American Protestant-based taxonomies of Pentecostalism and argues its limited value for settings such as Kerala, where the 'New Generation' churches split off from Orthodox churches. Barreto flags the absence of Latin American voices and experiences in World Christianity debates and points to the way in which African experiences have dominated in fashioning current conceptualization of World Christianity. Each of these contributions draws attention to the processes of exclusion and inclusion, and to privileging of certain voices and experiences in knowledge production in the academia over others, and flags how this selectiveness shapes theory as well as discourse. Thus, these observations pinpoint that power dynamics not merely play a role within Christianity/ies in past and present, but also in the representation and study of both current and past manifestations of Christianity.

\section{Typologies, Terminologies, and Conceptual Categories}

A second cluster of methodological issues that is central to a World Christianity approach, is a concern over the validity of typological and methodological categories in a diversity of local contexts. John's critical inquiry into taxonomies of Pentecostalism was already mentioned above. Likewise, also Barreto, Williams, Nagy and Frederiks argue that typologies and terminologies are developed in particular settings at particular moments in time, and hence may not be transferable to other settings nor may be apposite categories to study Christian manifestations worldwide. Several contributions in this volume explore this in some depth.

Frederiks and Nagy each examine the situationality of conceptual categories in their explorations, focusing in particular on the concept World Christianity itself. Frederiks, referencing work by scholars such as Paul Kollman, Thomas 
Thangaraj and Dana Robert, discusses the long genealogy and multiple recalibrations of World Christianity and argues that in its most recent stipulation, the discursive concept 'World Christianity'

is embedded in theories on the translatability and inculturation of the gospel (Sanneh 1989; Walls 199o, 1982) with a strong emphasis on the vitality and growth of 'Southern Christianity', most clearly expressed through the popular phrase that the 'center of gravity of Christianity is moving South'. The postulated but frequently implicit background to this conceptualization of World Christianity seems to be a representation of European Christianity as a tale of secularisation and decline. Against this context, the construct 'World Christianity' seems to function as a discursive reassurance that due to the 'meteoric rise of non-Western Christianity' (both in loci and in its migration settings) there is hope for the Christian faith after all.

Frederiks, this volume

Nagy in her contribution probes the modifier 'world' in World Christianity, and explores parallel 'worldling' trends within the Humanities (e.g. World Philosophy, World Literature and World History). She writes: "The recognition of a shared humanity seems to be one of the starting points based on which worlding approaches operate. While acknowledging the legitimacy of researching Christians and Christian communities worldwide (a position I repeatedly articulate), researching them does not mean a limited and exclusive attention to Christians only." And she concludes:

Placed in a global context, the modifier 'world' assumes multiple meanings, referring not only to geo-political places, but also to a diversity of perceptions, experiences, and processes of cohabitation within shared localities and beyond. This is why I argue that when placed before 'Christianity', 'world' may refer to parallel worlds within a shared locality, or worlds that are constructed and owned by people with different conceptual, ritual, and virtual domains, such as the digital world, the overlapping worlds of particular confessions or movements, or different social worlds.

Nagy, this volume

Van Liere's contribution on strategies of framing flags another issue. His casestudy of how Islamic State through media, words, and deeds constructs World Christianities, spells out that the conceptualization and stipulation of discursive categories is not merely the prerogative of the academia; concepts are also 
forged by public discourses, and by agents from within as well as outside the Christian tradition.

Corey Williams' and Stanley John's contributions both focus on the transferability of typologies and categories from one context to another. Williams' observations are more generic in nature. His inquiry into the notion of religious belonging establishes that analytical categories are often tailored on institutionalized forms of religion, making them unfit to study religion or religiosity that is less public or less institutionalized (like African indigenous religions). Williams also brings up the Protestant bias in the theorization of concepts pertaining to religion, and argues that categories tailored on Christianity may prove unsuitable for research in religiously plural settings. Stanley John in his quest for apposite taxonomies for Kerala's 'New Generation' churches, questions whether typologies developed based on a North American Protestant experience are meaningful categories to describe and analyze churches that emerged out of indigenous Pentecostal and Oriental Orthodox churches. His chapter represent a wider entreaty to interrogate the transferability of concepts and models developed on the basis of Christianity in Europe or North America and, like Frederiks and Barreto in their contributions, makes a case to extend World Christianity's multiple center approach to conceptual categories and periodization.

Finally, Haug's examination of the notions of 'karma' and 'God' sensitizes researchers to the fact that the use of analogous categories by informants does not necessarily imply that the notions have similar inferences. Haug shows that though her Christian informants indicated that the term karma could be used to describe Christian theological insights, none of them shared the cyclical understanding of reality this term implied. Likewise, some Buddhist informants, like Christian respondents, expressed the conviction, that God could intervene in the law of karma. Yet, where Christian respondents experienced this as hopeful and comforting, the Buddhist informants perceived this as something negative, because it implied "that the outcome of human action does not depend solely on one's own, but that it depends on someone outside of himself." Haug therefor makes clear that concepts never stand-alone but are always part of a wider discursive field that shapes their connotation.

Another methodological cluster that emerges from the chapters pertains to sources. The contributions address various aspects of what a World Christianity approach in relation to sources could involve. Paul van Geest's chapter on heresy in the works of Augustine of Hippo evidences that a World Christianity 
approach is productive for texts from the recent as well as the more distant past. Without explicitly using the term, Van Geest experiments with a World Christianity approach by reading patristic texts in a manner that acknowledges and affirms the pluriformity of Christianity's history. Van Geest's methodological choice to temporarily bracket out Augustine's standing as the bedrock of the Latin Church (a position attributed to him only in hindsight anyway), and to read Augustine's texts as one voice amidst others in the heresy debate, allows him to appreciate Augustine in his contextual connectivities. The chapter evidences how Augustine, rather than being an acontextual and a-historic authority, constantly rehashes his theological understandings of heresy, both in conversation with different opponents and in relation to altering religious and political circumstances. The chapter also makes clear that according to Augustine heterodox movements served a purpose in helping to establish 'orthodoxy'. Augustine's main objection to these movements- the claims of regional interpretations of Christianity to be normative for the whole of Christianity—sounds uncannily modern to people attuned to current World Christianity debates. Thus, Van Geest persuasively demonstrates that a World Christianity approach yields fresh perspectives, even for well-read patristic sources.

Both Emma Wild-Wood's chapter on studying the history of Christianity/ ies in Africa and Joseph Lee and Christie Chow's chapter on interpreting Christianity/ies in China, make working with sources the central concern of their contribution. Much has already been said and written about the "interpretation, problems and possibilities of working with missionary sources in the history of Christianity", to quote the title of Wild-Wood's chapter to this volume. In order to negotiate the limitations of their main archival sources both Wild-Wood and Lee and Chow devise multiple primary source strategies; by doing this, they are able to widen the scope of their source materials and incorporate multiple voices and perspectives. Wild-Wood, working mainly on colonial Africa, advocates the use of private papers as well as regional sources produced by local elites (e.g. anthropological works, newspapers) to complement missionary perspectives. Lee and Chow consulted government archives (national, regional, local), diaries, sermons, and personal papers (China being a highly literate society) and material culture as resources to supplement the (often scanty or absent) Chinese church archives. Chow also experimented with social media (Facebook/Twitter) to generate data. In their contributions both Wild-Wood and Lee and Chow make a convincing case for a historiography based on more than just internal Christian sources. They also argue that intersecting textual materials with oral history and material sources (e.g. photographs, films, audiotapes, grave-stones, and archaeological evidence) is a 
productive historiographic strategy to ensure the multiperspectivity central to a World Christianity approach.

In their discussion of sources Lee and Chow also raise the critical issue of language. They argue that drawing on sources in languages other than the dominant one can be an effective strategy to subvert or nuance hegemonic narratives. Also Wild-Wood draws attention to power dynamics in relation to sources. Examining the role of editors of missionary sources, Wild-Wood argues that an analysis of a story recurring in a variety sources may shed light on the trajectories of materials through editorial processes and reveal how narratives were fashioned to meet the expectations of particular audiences.

The multiple primary source method proposed by Wild-Wood and Lee and Chow may also prove to be an effective method to dispel some of the tenacious binaries (indigenous/missionary, north/south) that continue to mar many a contribution to the World Christianity debates (Jones 2014; Frederiks, this volume). Wild-Wood as well as Lee and Chow problematize bi-polar lines of thinking that pit missionary over and against indigenous perspectives, be it each for different reasons. Wild-Wood's work evinces that local agents like Apolo Kivebulaya were gradually drawn into universal missionary visions and cosmopolitan networks; Kivebulaya eventually became a cross-cultural missionary himself, thus in his very person blurring the categories of missionary and indigenous agent. For China, Lee and Chow criticize historiographic reproductions of the binary 'indigenous' versus 'missionary' because they replicate the nationalist agenda of the Communist state. Lee and Chow interrogate and contest this agenda by demonstrating that even during the Maoist era, local appropriation processes of missionary ideas continued, with extended kinship networks functioning as channels of transnational exchange.

Lee and Chow's chapter as well as Van Liere's contribution on discursive framings of the execution of Coptic migrant workers in January 2015 by Islamic State, flag one the concerns of a World Christianity approach, which is the situationality of concepts, theories, and sources. Both Lee and Chow and Van Liere demonstrate how sources are shaped by changing religious and political constellations. Their contributions signpost that institutions and organisationsthrough the production and framing of sources-have the power to shape both sources and realities. Their chapters also evidence how sources are produced and positioned to play a part in larger ideological frameworks and official historiographic narratives. Lee and Chow in their discussion of sources fashioned and fabricated by Maoist ideology, write: "[S]cholars have to be critical of the ideological settings in which these materials were produced, catalogued and preserved by government officials, and the anti-religious biases that were 
mobilized to interpret the faith experience of individual believers and church communities" (Lee and Chow, this volume). And as Van Liere's contribution makes clear, sources are not merely profoundly affected by ideologies, but at times are the products of power discourses and even orchestrated to support particular ideologies.

The cases of Is and Maoist China are two blatant examples of power dynamics at play. In many other cases the power dynamics will be more subtle, though no less effective, be it that the subtlety will also make power more elusive and hence more difficult to trace. Yet, as Frederiks argues in her contribution to in this volume, power is at the very heart of both knowledge production and knowledge construction.

\section{Methods}

Methodologically speaking, a World Christianity approach does not privilege particular methods. On the contrary, it fosters multi- and interdisciplinarity and as an approach interacts on existing methods, bringing certain themes and perspectives (e.g. power dynamics, multiple centers, connectivities, diversity) to the fore. The aim of a World Christianity approach is to create awareness of the complex methodological issues at stake when working with terms that are often taken for granted. As argued by Frederiks and Nagy in this volume, the very term World Christianity is a case in point. By using World Christianity as the name of an approach (rather than to describe a field of studies or a subject matter), the editors aim at testing its translatability and operationability through various methods and fields (as well as languages, and contexts).

By underscoring the fruitfulness of the multidisciplinarity and interdisciplinariy of a World Christianity approach the editors urge scholars to step out of their comfort zones and explore alternative methods, intersecting methods or even create new methods. Several contributions in this volume exemplify the productivity of such a venture. Van Geest's contribution for example shows how a World Christianity approach yields new research questions - and new insights - for traditional philological and theological text inquiries, even when applied to thoroughly scrutinized patristic sources as such as the Augustinian corpus. Van Liere's chapter shows the productiveness of intersecting a World Christianity approach with discourse analysis, evidencing that not only persons, objects or ideas, but also frames can construct religious connectivities. Van Liere demonstrates how frames, brought into play by actors as disparate as Is (crusader frame), Pope Francis (martyr/ecumenism of blood frame), and North American evangelicals (martyr/ 
convert frame), discursively interconnect religious communities across time and space, and fortify translocal bonds.

Wild-Wood and Lee and Chow expand well-worn historiographical methods by mining unconventional sources as well as by widening their scope to include non-textual sources, such as oral history and material culture. Wild-Wood uses a multiple primary source approach and triangulation to trace and engage a multiplicity of voices and perspectives, which enable her to probe longstanding conventional classifications and dichotomies (missionary/indigenous). Lee and Chow opt for a mixed method approach; intersecting historical and ethnographic methods aids Lee and Chow in meeting the challenges posed by the gaps in historical records as well as in interpreting sources profoundly shaped by Maoist ideology.

Both Williams and John primarily use ethnographic methods; but where John's investigation of Kerala 'New Generation' churches studies one particular group in multiple contexts, Williams investigates multiple groups in one particular locality. Frederiks in her contribution argues that such forms of synchronic (and diachronic) comparative research are an important feature of a World Christianity approach.

Williams operationalizes his comparative research into plural religious settings by introducing the notion of a 'religious field' (in his case: the Egúngún festival). Kari Haug in her chapter on Thai comparative theology opts for a different strategy. Rather than studying Thai Christians and Buddhists in a joint setting, Haug creates a common textual field (i.e. two passages from the Old Testament) and has representatives of both groups reflect on this, independently of each other. By creatively intersecting text-based research, comparative theology, and ethnography Haug is able to investigate how the predominantly Buddhist context of Thailand affects Thai Christian self-understanding. Her methodology and the data this yields, allow her to critically interrogate one dimensional 'translation'-type of analyses; her findings among people who share a worldview and culture, but whose religious socialization differs, show convergences as well as divergences. Haug argues that developing comparative theology into a more empirical direction could deepen scholarly knowledge about the complex interactions and negotiations of Christians in plural religious societies and could shed light on the multiple entanglements of religious traditions that co-exist in a given setting. She concludes by stating " $[t]$ hat using an empirical comparative theological approach in studying the phenomenon of World Christianity can contribute with in-depth knowledge of both the agency of local Christians and local and contextualized forms of Christian theology and practice" and "might sensitize and alert the researcher to the constructive theological work done by local Christians" (Haug, this volume). 
Douglas Pratt and Wesley Ariarajah also use theological methods to explore interreligious encounters, with Pratt mapping models and typologies of interreligious relating and Ariarajah reflecting on the multiple ways in which Christians and Christianity/ies shape and were shaped by the encounter with other religious traditions. While endorsing the necessity of re-conceptualizing Christian history/ies and theology/theologies on a more general level, Ariarajah concurrently argues that a reformulation that merely extends Western theology to accommodate 'non-Western theology' is not sufficiently radical. Reflecting on a life-time of interreligious encounters, Ariarajah calls upon World Christianity scholars to embark on a more fundamental theological project that interrogates the exclusivist claims undergirding most Christian theology/ies. In his contribution, Ariarajah therefore makes a case for a World Christianity project that encompasses all religious traditions and considers these traditions alongside Christianity to be part of the human 'heilsgeschichte', with resources salient to the Christian faith. Barreto seems to point in a similar direction, when he writes with approbation how the Commission for the Study of Church History in Latin America and the Caribbean (CEHILA) now studies the history of Christianity as part of the wider history of religions. Methodologically, the trend to study Christianity as a religious tradition amongst others, signals a new development. For most of its history, Christianity was mainly studied within a theological framework, with theological methods and conceptualized as 'church history'. Only recently, Christianity has become a subject matter for religious studies or anthropology. A World Christianity approach endorses and encourages these multidisciplinary approaches to Christianity/ies as well as initiatives to study Christianity/ies alongside other religious traditions or as part of a wider religious landscape.

\section{Unit of Analysis}

Several contributions in this volume flag the need for careful reflection in the processes of choosing a unit of analysis. The design of a research unit (conceptual, spatial, temporal) is a foundational building block in the construction of representation and impacts data generation, collection as well as data interpretation. Therefore, a thorough scrutiny of the pros and cons of choosing a particular set of criteria to demarcate the unit of analysis - and of the implications these choices have for the research-remains vital, especially for research projects purporting to employ a new lens or approach to the study of 
Christianity/ies. Corey Williams, in his chapter on multiple religious belonging in contemporary Nigeria for example, ruminates on conceptual demarcation. In his contribution Williams examines the fluidity of religious identities. He argues that a narrow conceptualization of religious belonging - one that hinges on formal criteria of religious belonging (e.g. membership) - prevents the researcher from seeing the diversity in modes of belonging. By widening the conceptual boundaries of religious belonging resulting in a broader research population, Williams designs a research unit that enables him to study a variety of modes of religious belonging. He writes:

This broadening allows for a wider range of belonging, which at times is official and formalized, while at other times more serendipitous, at times more public, while at other times mainly private. This more inclusive understanding provides two primary benefits. First, some religious traditions are more institutionally bound and public than others. For instance, participation in AIR [African Indigenous Religions, eds] is often private and without institutional (i.e. official) acceptance. Second, with a more institutional understanding of belonging, it is often those who exist on the margins of communities or privately belong who often end up being excluded from consideration.

Williams, this volume

Williams' deliberations on the most apt conceptualization of 'religious belonging' for his research raise several issues: they interrogate the suitability of conceptualizations and analytical categories that are tailored on Christianity (e.g. understanding belonging in terms of membership) for research in plural religious settings, and draw attention to the fluidity and transience of religious belonging, be it qualitatively over time, be it because "people can live and act across categorical boundaries of religions and are not necessarily limited to a singular religious affiliation", thus implicitly exposing the limitations of statistical approaches to religious belonging (Williams, this volume).

Williams' conceptual explorations of religious belonging also make him reconsider the spatial demarcation of his research unit. While acknowledging that an in-depth study of a single religious group or tradition will yield data concerning pluriformity, transnational networks or translocal connectivities, Williams draws on Birgit Meyer's and Marloes Janson's notion of a 'religious field' "in which several religious groups coexist in ever shifting dynamics of similarity and difference", to obtain a more dynamic research unit and to conduct longitudinal multi-site fieldwork at the popular and widely attended Yoruba Egúngún festival. He concludes: 
This highlights the necessity (...) for more multi-method, multi-site, longitudinal studies that are able to take such fluidity and context into account. For studies in World Christianity, this means expanding the horizon of religious life. In fieldwork studies, for instance, what happens in the town hall, forest festival, university club, etc., can be equally as important to research as the Sunday service or Wednesday night Bible study. Finding diverse angles, methods, and points in time to interrogate religious life is integral for a more holistic understanding.

Williams, this volume

Also Dorottya Nagy in her exploration of the modifier 'world' in World Christianity in this volume draws attention to the necessity of reflecting on the spatial demarcation of a research design. Nagy repeatedly cautions against tendencies that consider nation states "the sole analytic unit for research"; she entreats researchers working with a World Christianity approach to move beyond denominational labels or national institutions (e.g. churches) as research units, and makes a case for "an open understanding of space", studying

relations, the connections of Christians and Christian communities with larger social settings, and avoiding internalist paradigms. Such a research focus does not recreate the old Christian and non-Christian dichotomy, but looks at cohabitation or living together from the perspective of a shared humanity, and at boundaries set by complex power relations.

Nagy, this volume

Raimundo Barreto alerts the readers to the temporal properties of a research unit. Extensively referencing Enrique Dussel's life-long quest for a revision of the Eurocentric periodization of Latin America's history with Christianity, Barreto highlights the importance of critical inquiry into the terminus a quo et ad quem of research designs, and states that there needs to be correlation between the locus of research and the temporal demarcations used. Where Barreto discusses temporal concerns in relation to the locality of the research, Emma Wild-Wood flags temporal concerns in relation to sources. In her chapter on the problems and possibilities of missionary sources in the history of Christianity, Wild-Wood signals that researchers often tend to underpin their temporal demarcations by referencing matters extraneous to the context (e.g. the start date of an archival corpus or the arrival of missionaries in a certain area), thus not only re-enforcing a familiar periodization, but also unaware that through such a demarcation rationale, contextual continuities such as "prior 
healing, renewalist or resistance movements can be overlooked" (Wild-Wood, this volume).

\section{$7 \quad$ In Conclusion}

This volume has been a quest in methodology. At heart of this quest has been the proposal to consider World Christianity to be a particular multidisciplinary and interdisciplinary approach of studying Christianity/ies in past and present, an approach that is sensitive to the multiple perspectives, manifestations, contexts and actors of Christianity/ies as well as to the translocal connectivities, and integrative forces that conjoin these local Christianities. Based on the methods, observations, and insights of the contributors to this volume, in this closing chapter we have presented five methodological clusters that tentatively begin to sketch the contours of what such a World Christianity approach could entail. The approach is still very much in the making. We hope that proposal will evoke much discussion, so that the tentative contours will slowly begin to crystalize, eventually resulting in a dynamic multi-disciplinary and interdisciplinary approach of studying and narrating Christianity/ies' (hi)stories from multiple perspectives. 